\title{
Consistent habitat segregation between sexes in the spider crabs Maja brachydactyla and Maja squinado (Brachyura), as revealed by stable isotopes
}

\author{
Guillermo Guerao ${ }^{1}$, Guiomar Rotllant ${ }^{2}$, Enric Gisbert ${ }^{3}$, Marc Uyà ${ }^{4}$, Luís Cardona ${ }^{4}$ \\ ${ }^{1}$ PS Fabra i Puig, 344, Barcelona, Spain. E-mail: gguerao@ gmail.com \\ ${ }^{2}$ Institut de Ciències del Mar, CSIC. Passeig marítim de la Barceloneta 37-49. 08003 Barcelona, Spain. \\ ${ }^{3}$ IRTA, Cultius Aquàtics, Ctra. Poble Nou, km 5.5, 43540 Sant Carles de la Ràpita, Tarragona, Spain. \\ ${ }^{4}$ Departament de Biologia Animal and Institut de Recerca de la Biodiversitat (IRBio), Faculty of Biologia, \\ University of Barcelona, Avinguda Diagonal 643, 08028 Barcelona, Spain.
}

\begin{abstract}
Summary: Differences in the resource use patterns of males and females of the spider crab species Maja brachydactyla Balss, 1922 and M. squinado (Herbst, 1788) from several geographic areas (three in the Atlantic and two in the Mediterranean) were studied through the analysis of stable isotopes of carbon and nitrogen in the exoskeleton of post-pubertal (adult) specimens. Results confirmed that males and females from the same population usually did not differ in $\delta^{15} \mathrm{~N}$ values and hence foraged at the same trophic level. In contrast, females were usually enriched in ${ }^{13} \mathrm{C}$ as compared with males from the same population, thus suggesting that females use shallower habitats than males before the terminal moult. The results reported here also indicate that stable isotopes can be useful for the traceability of commercial Maja species, but only if species and sex are incorporated in the analysis.
\end{abstract}

Keywords: Maja brachydactyla; Maja squinado; stable isotopes; trophic level; sexual segregation; traceability.

Segregación sexual del hábitat en los centollos Maja brachydactyla y Maja squinado (Brachyura) revelada mediante isótopos estables

Resumen: Se estudiaron mediante el análisis de isótopos estables de carbono y nitrógeno en el exoesqueleto de ejemplares adultos las diferencias en los patrones de uso de recursos de los machos y las hembras de los cangrejos Maja brachydactyla Balss, 1922 y M. squinado (Herbst, 1788) procedentes de varias zonas geográficas (tres en el Atlántico y dos en el Mediterráneo). Los resultados confirmaron que los machos y las hembras de la misma población, por lo general, no difieren de los valores de $\delta^{15} \mathrm{~N}$ y por lo tanto se alimentaban en el mismo nivel trófico. En contraste, las hembras por lo general se hallan enriquecidas en ${ }^{13} \mathrm{C}$ en comparación con los machos de la misma población, lo que sugiere que las hembras ocupan hábitats menos profundos que los machos antes de la muda terminal. Los resultados aquí presentados indican también que los isótopos estables pueden ser útiles para la trazabilidad de las especies comerciales del género Maja, pero sólo si la identidad de la especies y el sexo del ejemplar se incorporan al análisis.

Palabras clave: Maja brachydactyla; Maja squinado; isótopos estables; nivel trófico; segregación sexual; trazabilidad.

Citation/Como citar este artículo: Guerao G., Rotllant G., Gisbert E., Uyà M., Cardona L. 2016. Consistent habitat segregation between sexes in the spider crabs Maja brachydactyla and Maja squinado (Brachyura), as revealed by stable isotopes. Sci. Mar. 80(1): 103-110. doi: http://dx.doi.org/10.3989/scimar.04236.23B

Editor: C. Zeng.

Received: March 10, 2015. Accepted: October 28, 2015. Published: January 20. 2016.

Copyright: () 2016 CSIC. This is an open-access article distributed under the Creative Commons Attribution-Non Commercial Lisence (by-nc) Spain 3.0.

\section{INTRODUCTION}

The spider crabs of the genus Maja Lamarck, 1801 (Majoidea: Majidae), with around 20 described species worldwide, are represented on European coasts by four species: M. brachydactyla (Balss, 1922), M. crispata
(Risso, 1827), M. goltziana (D'Oliveira, 1888) and M. squinado (Herbst, 1788) (Neumann 1998, $\mathrm{Ng}$ et al. 2008, Sotelo et al. 2008, 2009). M. brachydactyla and $M$. squinado are the largest European species of the genus and are found from subtidal areas to about 90 m depth (De Kergariou 1984, Števčić 1973). M. 
brachydactyla inhabits the eastern Atlantic from the British Isles to Senegal and has a high commercial value, while $M$. squinado inhabits the Mediterranean and is considered an endangered species (UNEP 1996, Freire et al. 2002, Martín et al. 2012, Sotelo et al. 2008, Guerao and Rotllant 2010, Guerao et al. 2011, Abelló et al. 2014), although it was abundant until the first half of the $20^{\text {th }}$ century (Pons Muñoz 1994). Until recently, $M$. brachydactyla was considered a synonym of $M$. squinado (Zariquiey-Álvarez 1968, Neumann 1996, 1998, Ng et al. 2008), but molecular studies indicated that $M$. squinado is more closely related to $M$. crispata than to M. brachydactyla (Sotelo et al. 2009). Molecular analysis also revealed that the divergence between $M$. brachydactyla and M. squinado-M. crispata clade occurred in the Miocene (9.5 mya) and the divergence between $M$. squinado and $M$. crispata, occurred in the Pliocene (3.9 mya). Accordingly, the large morphological resemblance between $M$. brachydactyla and $M$. squinado could be also due to convergent evolution (see Neumann 1996, 1998, Sotelo et al. 2008, 2009 for taxonomic status). A diagnostic tool was developed to identify the four species of Maja in Europe with morphological and molecular methods (Guerao et al., 2011). Adults of M. brachydactyla and M. squinado are commercially exploited species and a simple relationship between carapace length (CL) and antorbital spine length could be used to differentiate the two species.

Marine brachyuran crabs are usually opportunistic consumers (Števčić 1967, Choy 1986, Abelló and Cartes 1987, Abelló 1989) and this is also true for $M$. brachydactyla according to studies based on stomach contents (De Kergariou 1974, Bernárdez et al. 2000): $M$. brachydactyla feed on a large variety of preys, consuming 50\% of algae and a mixture of animals (mollusks, crustaceans, echinoderms, etc.). De Kergariou (1974) and Bernárdez et al. (2000) found differences in the diet between males and females and between juveniles and adults which they attributed to an uneven bathymetric distribution, a pattern typical of many large brachyuran crabs (e.g. Bennett and Brown 1983, Hines et al. 1987, Spivak et al. 1994). However, recent research using stable isotopes has failed to find any differences between sexes in diet or habitat use patterns either in adults (Bodin et al. 2007) or juveniles (Bodin et al. 2007, Freire et al. 2009).

Stable isotope ratios of carbon and nitrogen are widely used in ecology for the study of trophic relationships and habitat use patterns, because the stable isotope ratios in a consumer's tissues reflect those in the diet, which in turn depends on the relative availability of the light and heavy isotopes of each element for primary producers (Hobson 1999, Koch 2008, Graham et al. 2010). Marine macrophytes are typically enriched in ${ }^{13} \mathrm{C}$ compared with phytoplankton, but macrophytes occur only in shallow waters and hence the stable isotope ratio of carbon consumers typically decreases with depth in coastal areas (e.g. Cardona et al. 2007, Drago et al. 2009, Freire et al. 2009, Pinela et al. 2010). Accordingly, the stable isotope ratio of carbon can be used to explore intraspecific differences in bathymetric distribution by sex or age, although tissue selection is critical because stable isotope turnover rates are tissuedependent (Martínez del Río et al. 2009).

Previous studies on $M$. brachydactyla using stable isotope ratios concluded that no sexual difference existed in diet or habitat use (Freire et al. 2009, Bodin et al. 2007), in contrast with earlier studies based on stomach contents (De Kergariou 1974, Bernárdez et al. 2000). This incongruence may be due to the fact that they analysed tissues with a relatively high turnover rate sampled from specimens collected from the same habitat. This experimental design was useful to assess the existence of dietary differences between groups in the same habitat, but likely failed to detect any previous habitat segregation.

Tissues that remain inert after synthesis (e.g. feathers, hair, nails and arthropod exoskeleton) are a good choice for the study of habitat use patterns, as they record the unmodified stable isotope ratios of the habitat where they were formed (Hirons et al. 2001, Cherel and Hobson 2005). The organic matter in the exoskeleton, a mixture of chitin and proteins, offers a good alternative, as the stable isotope ratios of arthropod exoskeleton remain stable after synthesis (Hobson et al. 1999) and spider crabs have a terminal moult, i.e. they do not moult after the moult of maturity. The last intermoult period is the longest representing several months (González-Gurriarán et al. 1995, Corgos et al. 2007). During the moulting process, energy reserves are used to form the exoskeleton of these crabs (Vernet and Charmantier 1994), so the imprint of feeding during the last intermoult will be recorded in the carapace of the crabs. Thus, stable isotope ratios in the carapace are expected to represent a long-term signal of habitat use, compared to muscle and hepatopancreas tissues.

The aim of this study was to test the hypothesis that, within every population of $M$. brachydactyla and $M$. squinado, males and females forage at the same trophic level but differ in bathymetric distribution, and that this pattern is consistent across populations and species.

\section{MATERIALS AND METHODS}

\section{Sampled individuals}

In 2007-2009, 98 adult specimens of M. brachydactila and $M$. squinado (CL=141 $\pm 20 \mathrm{~mm}$ ) were collected by commercial fishery vessels in the Atlantic and Mediterranean Sea (Table 1, Fig. 1). Males and females were collected during the same sampling trials from all localities, except from Morocco, where only males were available.

\section{Stable isotope analysis}

Exoskeleton samples were collected from the propodus and dactylus segments without debris areas of the pereiopods of individuals from each population and sex. Exoskeletons were chosen to have at least a oneyear signature integrating fed intake in a broad area of distribution where specimens lived and fed.

Samples were stored frozen at $-20^{\circ} \mathrm{C}$, thawed, and dried at $60^{\circ} \mathrm{C}$ for $48-72 \mathrm{~h}$. Then, each sample was sub- 
Table 1. - Sampling locations for isotope studies of Maja brachydactyla and Maja quinado.

\begin{tabular}{|c|c|c|c|c|}
\hline Species & Collection sites & $\mathrm{n}$ & Coordinates & year \\
\hline \multirow[t]{3}{*}{ M. brachydcatyla } & E Atlantic (Galicia, Spain) & 19 & $42^{\circ} 16^{\prime} 00.22^{\prime \prime} \mathrm{N} ; 9^{\circ} 01^{\prime} 04.99^{\prime \prime} \mathrm{W}$ & $2007-08$ \\
\hline & E Atlantic (Grand Casablanca, Morocco) & 31 & $33^{\circ} 49^{\prime} 43.58^{\prime \prime} \mathrm{N} ; 7^{\circ} 25^{\prime} 40.17^{\prime \prime} \mathrm{W}$ & 2009 \\
\hline & SW Mediterranean (Ceuta, Spain) & 10 & $35^{\circ} 40^{\prime} 19.199^{\prime} \mathrm{N} ; 5^{\circ} 34$ '46.82”W & 2009 \\
\hline \multirow[t]{2}{*}{ M. squinado } & W Mediterranean (Catalonia, Spain) & 15 & $42^{\circ} 08^{\prime} 22.75^{\prime \prime} \mathrm{N} ; 3^{\circ} 29^{\prime} 40.01^{\prime \prime} \mathrm{E}$ & 2007-09 \\
\hline & Central Mediterranean (Adriatic Sea, Italy) & 23 & $43^{\circ} 40^{\prime} 59.56^{\prime \prime N} ; 13^{\circ} 46^{\prime} 02.53^{\prime \prime} \mathrm{E}$ & 2009 \\
\hline
\end{tabular}

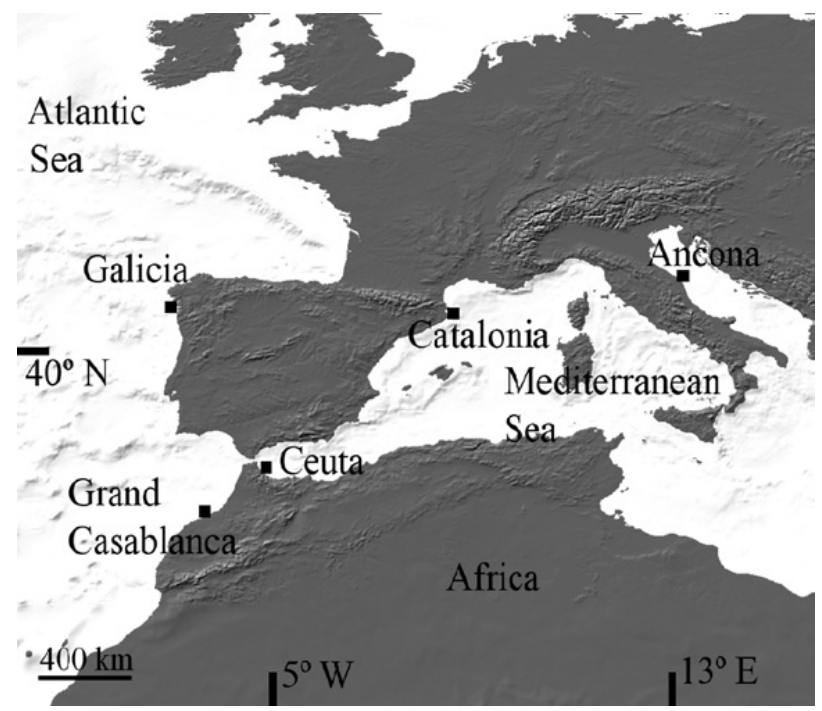

Fig. 1. - Map of sampling locations for isotope studies of Maja brachydactyla and Maja quinado.

divided in two sub-samples. Lipids were removed from one of them by rinsing the powdered samples several times with a 2:1 chloroform:methanol solution (Bligh and Dyer 1959). The same sub-samples were then treated for decarbonation with a $0.5 \mathrm{M}$ hydrochloric acid $(\mathrm{HCl})$ solution (e.g. Drago et al. 2009, Eder et al. 2012). As lipid extraction and decarbonation with $\mathrm{HCl}$ may affect the $\delta^{15} \mathrm{~N}$ values (Bunn et al. 1995, Yokoyama et al. 2005), the untreated exoskeleton samples were used to measure $\delta^{15} \mathrm{~N}$. One milligram of sample was used for $\delta^{15} \mathrm{~N}$ determination and $0.5-0.7 \mathrm{mg}$ of sample was used for $\delta^{13} \mathrm{C}$ determination. The samples were weighed in tin cups $(3.3-5 \mathrm{~mm})$ and combusted in a continuous-flow isotope-ratio mass spectrometer (Flash 1112 IRMS Delta C Series EA, Thermo Finnigan, Bremen, Germany). The samples were processed at the Serveis Científics i Tecnològics of the University of Barcelona.

Isotopic composition was expressed in the standard $\delta$ notation in parts per thousand (\%o) relative to predefined international standards, V-PDB (Vienna Pee Dee Belemnite) calcium carbonate for $\delta^{13} \mathrm{C}$ and atmospheric $\mathrm{N}_{2}$ (air) for $\delta^{15} \mathrm{~N}$, according to:

$$
\delta \mathrm{X}=\left[\left(R_{\text {sample }} / R_{\text {standard }}\right)-1\right] 10^{3}
$$

where $\mathrm{X}$ is ${ }^{13} \mathrm{C}$ or ${ }^{15} \mathrm{~N}, R_{\text {sample }}$ is the heavy-light isotope ratio of the sample $\left({ }^{13} \mathrm{C} /{ }^{12} \mathrm{C}\right.$ or $\left.{ }^{15} \mathrm{~N} /{ }^{14} \mathrm{~N}\right)$ and $R_{\text {standard }}$ is the heavy-light isotope ratio in the reference standards. The conventional use of these internationally accepted standards with relatively low and high levels of ${ }^{13} \mathrm{C}$ and ${ }^{15} \mathrm{~N}$, respectively, results in negative carbon and positive nitrogen isotope values. The international stable isotope secondary standards of known ${ }^{13} \mathrm{C} /{ }^{12} \mathrm{C}$ ratios, as given by the International Atomic Energy Agency (IAEA, Vienna, Austria), namely polyethylene (IAEA $\mathrm{CH}_{7}, \delta^{13} \mathrm{C}=-31.8 \%$ ), L-glutamic acid (IAEA USGS $40, \delta^{13} \mathrm{C}=-26.3 \%$ ) and sucrose (IAEA $\mathrm{CH}_{6}, \delta^{13} \mathrm{C}=-10.4 \%$ ), were used for calibration at a precision of $0.2 \%$. For nitrogen, international stable isotope secondary standards of known ${ }^{15} \mathrm{~N} /{ }^{14} \mathrm{~N}$ ratios, namely $\left(\mathrm{NH}_{4}\right)_{2} \mathrm{SO}_{4}\left(\mathrm{IAEA} \mathrm{N} 1, \delta^{15} \mathrm{~N}=+0.4 \%\right.$ and IAEA $\left.\mathrm{N} 2, \delta^{15} \mathrm{~N}=+20.3 \% 0\right)$, L-glutamic acid $\left(\delta^{15} \mathrm{~N}=-4.5 \%\right.$, and caffeine (IAEA $600 \delta^{15} \mathrm{~N}=+.0 \%$ ), were used to a precision of $0.3 \%$.

\section{Data analysis}

Two-way analysis of variance (ANOVA) ( $\operatorname{sex} x$ population) was used to test whether males and females differed in $\delta^{13} \mathrm{C}$ and $\delta^{15} \mathrm{~N}$ values consistently across populations and species. As only males were available from Morocco, one-way ANOVA was used to analyse the effect of population on the stable isotope ratios of males.

We estimated the isotopic niche width using the convex hull area in the isotopic space defined by $\delta^{13} \mathrm{C}$ and $\delta^{15} \mathrm{~N}$ (Layman et al. 2007). However, the use of Euclidean methods, such as convex hulls to define the isotopic niche space of a species in a community (Layman et al. 2007), is subject to sampling biases and sensitive to sample size (Jackson et al. 2011). The standard ellipse areas estimated by Bayesian inference can incorporate uncertainties such as sampling biases and small sample sizes into niche metrics (Jackson et al. 2011). Then we estimated the width of the isotopic niche at the population level using the Bayesian standard ellipse area by the function SIBER (Stable Isotope Bayesian Ellipses in R; Jackson et al. 2011) of the library SIAR (Stable Isotope Analysis in R; Parnell et al. 2010) in the free software R (R Core Team 2013). Furthermore, we calculated the magnitude of the isotopic overlap between sexes in each population based on 100000 posterior draws of the standard ellipse areas corrected for small sample size parameters (Jackson et al. 2011). This approach, based on Markov-chain Monte Carlo simulation, assigns measures of uncertainty to construct parameters of ellipses in a similar way to a bootstrap.

Discriminant Analysis was applied to $\delta^{13} \mathrm{C}$ and $\delta^{15} \mathrm{~N}$ to test their reliability when used for individual assignation to the population of origin.

\section{RESULTS}

Figure 2 shows the $\delta^{13} \mathrm{C}$ and $\delta^{15} \mathrm{~N}$ values of males and females of M. brachydactyla and M. squinado 


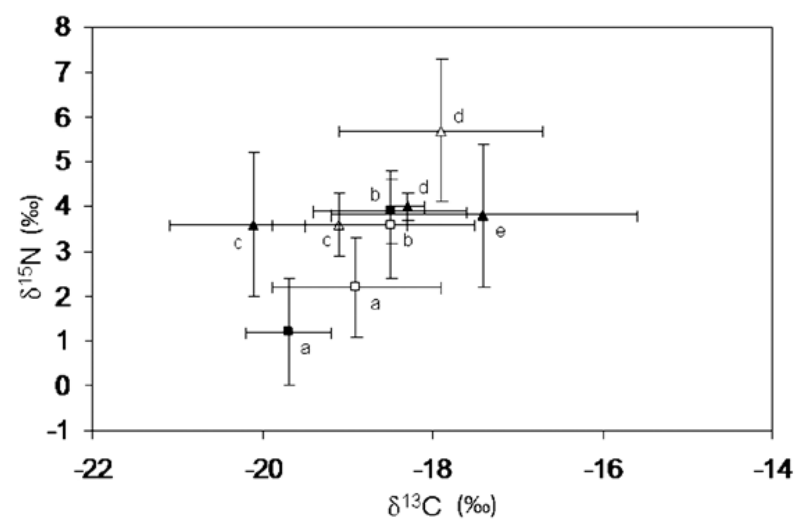

Fig. 2. - Distribution of $\delta^{13} \mathrm{C}$ and $\delta^{15} \mathrm{~N}$ values (mean $\pm \mathrm{SD}$ ) among population and sex of Maja brachydactyla (triangles) and M. sqinado (squares). Sex is denoted by colour (males, black; females, white) and population by letter: a, Ancona; b, Catalonia; c, Ceuta; d, Galicia; e, Morocco.

from the five considered populations. Males were consistently depleted in ${ }^{13} \mathrm{C}$ when compared with females from the same population (ANOVA, model: $\mathrm{F}_{7.64}<0.001$, sex: $\mathrm{F}_{1.64}<0.023$, population, $\left.\mathrm{F}_{3.64}<0.001\right)$. Furthermore, differences among populations were unrelated to species identity, as a Tukey post-hoc test revealed differences between the $\delta^{13} \mathrm{C}$ of $M$. brachydactyla from Ceuta and Galicia, but no differences between the $\delta^{13} \mathrm{C}$ of $M$. brachydactyla from Ceuta and that of $M$. squinado from Ancona or between the $\delta^{13} \mathrm{C}$ of $M$. squinado from Catalonia and the $\delta^{13} \mathrm{C}$ of $M$. brachydactyla from Galicia (Table 2). That geographic pattern did not change when the males from Morocco were incorporated into the analysis and all the females were removed (ANOVA, model: $\mathrm{F}_{4.42}<0.001$ ), as a Tukey post-hoc test revealed differences between the $\delta^{13} \mathrm{C}$ of $M$. brachydactyla from Ceuta and those from Galicia and Morocco but no differences between the $\delta^{13} \mathrm{C}$ of $M$. squinado from Catalonia and the $\delta^{13} \mathrm{C}$ of $M$. brachydactyla from Galicia and those from Morocco.

Statistically significant differences were observed among populations for $\delta^{15} \mathrm{~N}$ values, but differences between sexes were not consistent across populations, although results were on the verge of similarity (ANOVA, model: $\mathrm{F}_{7.64}<0.001$, sex: $\mathrm{F}_{1.64}<0.083$, population, $\left.\mathrm{F}_{3.64}<0.001\right)$. Differences among populations were also unrelated to species identity, as a Tukey post-hoc test revealed differences between the $\delta^{15} \mathrm{~N}$ of $M$. brachydactyla from Ceuta and Galicia but no differences between the $\delta^{15} \mathrm{~N}$ of $M$. squinado from Catalonia and the $\delta^{15} \mathrm{~N}$ of $M$. brachydactyla from Galicia (Table 2). The same was true when the females were removed from the analysis and the males from Morocco were incorporated, as only the males of $M$. squinado from Ancona were statistically different from the males of M. squinado from Catalonia and those of M. brachydactyla from Ceuta, Morocco and Galicia (ANOVA, model: $\mathrm{F}_{4.42}<0.001$ : Table 2).

The Bayesian ellipses of females were larger than those of males in the population of $M$. brachydactyla from Galicia and in the two populations of M. squinado from Catalonia and Ancona, whereas the opposite was true for the population of $M$. brachydactyla from Ceuta
Table 2. - Results of the Tukey post-hoc tests. Values are the regional averages.

\begin{tabular}{llccc}
\hline Design & Location & \multicolumn{3}{c}{ Homogenous clusters } \\
& & Group 1 & Group 2 & Group 3 \\
\hline${ }^{13} \mathrm{C}$; both sexes & Ceuta & -19.6 & & \\
& Ancona & -19.3 & -19.3 & \\
& Catalonia & & -18.5 & -18.5 \\
& Galicia & 1.7 & & -18.1 \\
${ }^{15} \mathrm{~N}$; both sexes & Ancona & & 3.6 & \\
& Ceuta & & 3.8 & 3.8 \\
& Catalonia & & & 5.0 \\
& Galicia & -20.1 & & \\
${ }^{13} \mathrm{C}$; males & Ceuta & -19.6 & -19.6 & \\
& Ancona & & -18.5 & \\
& Catalonia & & -18.3 & -18.3 \\
& Galicia & & & -17.1 \\
& Morocco & 1.2 & 3.6 & \\
${ }^{15} \mathrm{~N}$; males & Ancona & & 3.9 & \\
& Ceuta & & 3.9 & \\
& Catalonia & & 4.0 & \\
& Galicia & & 4.5 & \\
& Morocco & & & \\
\hline
\end{tabular}
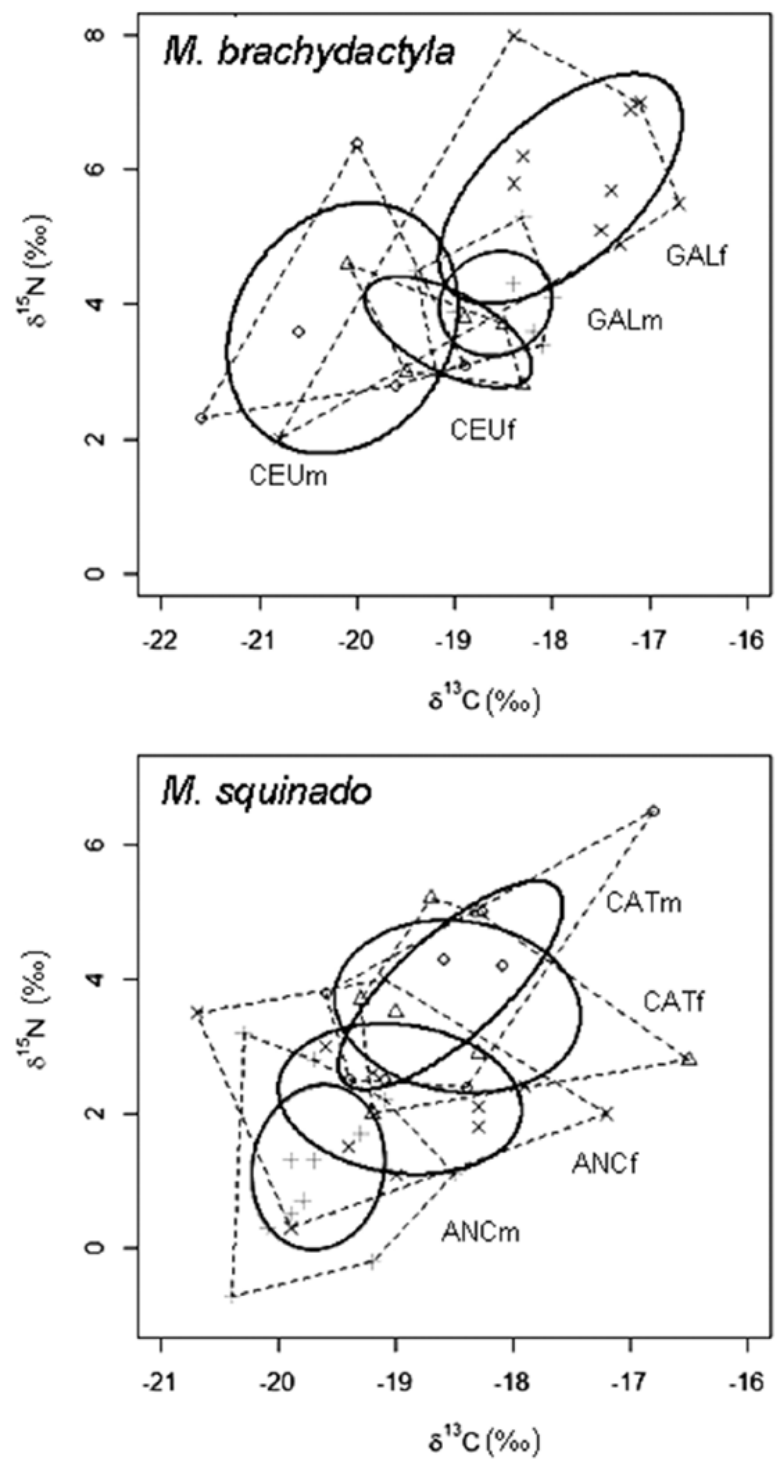

Fig. 3. - Bayesian standard ellipse areas (solid lines) and their respective convex hulls (dashed lines) for Maja brachydactyla (top panel) and Maja squinado (bottom panel), calculated by SIBER using the bivariate isotopic values (individual symbols) of each species, population and sex. 


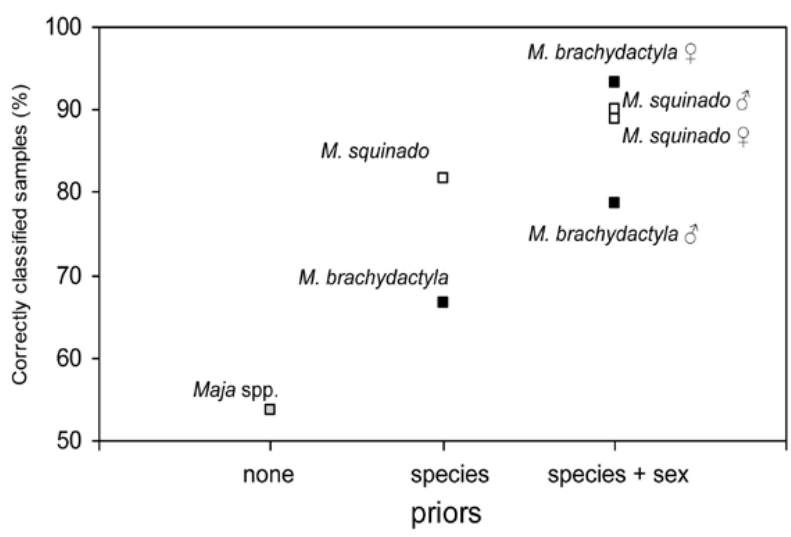

Fig. 4. - Performance of discriminant analysis based on $\delta^{13} \mathrm{C}$ and $\delta^{15} \mathrm{~N}$ without any prior information, incorporating species identity, and incorporating species and sex.

(Fig. 3). Everywhere, the overlap of the Bayesian ellipses of both sexes was highly asymmetrical. In the population of $M$. brachydactyla from Galicia and in the two populations of $M$. squinado from Catalonia and Ancona, the overlap area represented a larger fraction of the surface of the male ellipses than that of the female ellipses $(42.1 \%$ vs. $11.3 \%, 74.3 \%$ vs. $52.9 \%$ and $32.6 \%$ vs. $19.7 \%$ respectively), whereas the opposite was true for the population of $M$. brachydactyla from Ceuta (males, $13.8 \%$; females, $53.5 \%$ ).

Discriminant analysis ignoring species and sex classified correctly only $53.7 \%$ of the samples (Fig. 4), which is significantly higher than expected by chance but too low for traceability. Individual assignation improved when discriminant analysis was run independently for each species, as $81.6 \%$ of the samples of M. squinado and $66.7 \%$ of those of $M$. brachydactyla were classified correctly. The highest accuracy was achieved when the discriminant analysis was run independently for the males and females of each species (Fig. 4). Figure 4 shows the accuracy of individual assignments for each species, sex and locality. The lowest accuracy was achieved for males of $M$. brachydactyla from Galicia $(70 \%)$ and the highest for the females of the same species from Ceuta $(100 \%)$ and males of $M$. squinado from Ancona (100\%).

\section{DISCUSSION}

Maja brachydactyla is an opportunistic species that consumes any range of food items that is available (Števčić 1967, De Kergariou 1974, Bernárdez et al. 2000). Although there are no studies on the feeding habits of M. squinado, it seems quite possible that this species is also an opportunistic feeder. Both species have a complex biological cycle, with varying habitat requirements and changes in behaviour depending on the growth phase and the specific time period in the life history (Števčić 1973, González-Gurriarán and Freire 1994, Hines et al. 1995, González-Gurriarán et al. 2002). The juvenile stage lasts approximately two years until a terminal moult, at which time sexual maturity is achieved (González-Gurriarán et al. 1995, Hines et al. 1995, Sampedro et al. 1999). After the terminal moult, the adult individuals migrate to deeper waters (González-Gurriarán et al. 2002), where mating probably occurs. Only the adult females return to the shallower waters to spawn. In terms of carbon and nitrogen stable isotopic composition, tissues with high turnover rates (muscle and hepatopancreas) reflect the diet in the short term, and could be indicative of differences in diet during the days or weeks previous to their capture and analysis (Freire et al. 2009). However, the carapace provides an integrated signal of the animal assimilated diet on a long-term time scale (Hobson et al. 1999). In the present study, all animals were postpubertal specimens and their exoskeleton was formed before the terminal moult (Sampedro et al. 1999). Therefore, isotope signatures may provide insight into the trophic preferences during the last intermoult period before the animals reached sexual maturity $(<3$ months; Corgos et al. 2007).

As expected, the stable isotope ratios of carbon and nitrogen in M. brachydactyla and M. squinado differed dramatically among populations, independently of species identity, hindering the capacity of stable isotopes for traceability unless species and sex are included in the analysis as priors. The relative abundance of ${ }^{15} \mathrm{~N}$ in marine primary producers and their consumers depends on the balance of fixed and recycled nitrogen and is usually very low in oligotrophic regions (Graham et al. 2010, Somes et al. 2010), so it is lower in the Mediterranean than in the adjoining Atlantic (e.g. Borrell et al. 2006, Gómez-Díaz and González-Solís 2007, Giménez et al. 2013). Actually, the lowest $\delta^{15} \mathrm{~N}$ values were observed in the specimens of $M$. squinado from Ancona, likely to be captured in the northern Ionian Sea, a region characterized by very low $\delta^{15} \mathrm{~N}$ values in particulate organic matter (Pantoja et al. 2002). Moreover, the relative abundance of ${ }^{13} \mathrm{C}$ in marine primary producers and their consumers depends on the availability of inorganic carbon within their boundary layer, which in turn depends on primary productivity, water turbulence, and plant architecture (Post 2002). Interestingly, the highest values were observed in specimens from Morocco, Galicia and Catalonia, which are the most productive of the five regions considered (Longhurst 1998, Bosc et al. 2004). This result suggests that the highest interpopulation variability in the $\delta^{13} \mathrm{C}$ values of the two species of crabs considered here depends on the intensity of the regional primary productivity, although other factors such as differences in the arrival of terrestrial allochthonous organic matter may also play a role.

The $\delta^{13} \mathrm{C}$ values within an area are also influenced by depth, because macrophytes are typically enriched in ${ }^{13} \mathrm{C}$ when compared with phytoplankton in both the Atlantic (Freire et al. 2009) and the Mediterranean (Cardona et al. 2007), but macrophytes occur only in shallow waters. As a consequence, the $\delta^{13} \mathrm{C}$ values typically decrease in deeper, off-shore habitats as compared with shallow, on-shore habitats where the relevance of macrophytes as a source of organic carbon is higher (e.g. Cardona et al. 2007). In this scenario, the consistent enrichment in ${ }^{13} \mathrm{C}$ of females across populations and species suggests that female spider crabs use 
shallower habitats than males before the post-pubertal moult. Furthermore, Bayesian ellipses show that sexes differ dramatically in the breadth of their isotopic niches in all the populations studied and that females usually have a broader isotopic niche than males, except for M. brachydactyla in Ceuta.

These results are in agreement with the strong evidence that spatial and seasonal segregation exists by sex between adults and reproductive stage in this group of species (De Kergariou 1971, 1984, Števčić 1973, Rodhouse 1984, González-Gurriarán and Freire 1994, González-Gurriarán et al. 2002, Corgos et al. 2007, Fahy and Carroll 2009). M. brachydactyla adults migrate to deep water in association with gonad maturation and the development of seminal receptacles in the females. They return to shallow inshore water to incubate eggs and release larvae. However, males migrate longer distances than females (Fahy and Carroll 2009). Our results suggested that males and females may be spatially segregated before the terminal (pubertal) moult, as indicated by $\delta^{13} \mathrm{C}$ values in their exoskeletons, indicating that pre-pubertal males migrate to deeper waters than females, though females may remain in shallow waters and migrate to deep water mainly for coupling. However, $\delta^{13} \mathrm{C}$ short-term isotopic signature values in the muscle of migrating males and females were similar in M. brachydactyla from western Brittany (Bodin et al. 2007), indicating that both sexes co-habited and preyed on similar food items during migratory periods.

The $\delta^{15} \mathrm{~N}$ values of individuals from the same species inhabiting the same area may also vary, depending on their trophic level (Post 2002). In the present study, the absence of statistically significant differences between sexes for $\delta^{15} \mathrm{~N}$ suggests that males and females did not differ consistently in their trophic level, although differences may exist in some populations. Experiments in captivity suggest that the exoskeleton of crustaceans has a negative ${ }^{15} \mathrm{~N}$ fractionation, in contrast with the positive fractionation of muscle (Yokoyama et al. 2005). These differences explain why the $\delta^{15} \mathrm{~N}$ values reported here are much lower than those reported for the muscle of M. brachydactyla (Bodin et al. 2007, Freire et al. 2009). Considering an average diet-toexoskeleton fractionation of $-2.4 \%$ reported by Yokohama et al. (2005), the $\delta^{15} \mathrm{~N}$ values reported here for $M$. brachydactyla from Galicia suggest a diet with a $\delta^{15} \mathrm{~N}$ value of approximately $7.4 \%$, consistent with an omnivorous diet with a strong plant component according to the regional isospace (Freire et al. 2009). Likewise, the $\delta^{15} \mathrm{~N}$ values reported here for $M$. squinado from the Mediterranean $\left(2.5 \%\right.$ ) suggest a diet with a $\delta^{15} \mathrm{~N}$ value of approximately $4.9 \%$, also consistent with an omnivorous diet with a strong plant component according to the regional isospace (Cardona et al. 2007).

Stomach content studies have shown that macroalgae were food items of importance in the diet of these species (Števčić 1967, Bernárdez et al. 2000). Isotopic signals from the current study suggested that macroalgae seemed to be better digested and assimilated than other preys ingested (e.g. crustaceans, mollusks and echinoderms). This hypothesis is supported by the high level of $\alpha$-amylase activities found in adult specimens held in captivity, which were one order of magnitude higher than total proteases (Rotllant et al. 2013). In the present study, differences between sexes for $\delta^{15} \mathrm{~N}$ values were significant for populations of $M$. brachtylatyla from Galicia and M. squinado from Ancona. The low $\delta^{15} \mathrm{~N}$ values observed in males indicate a higher capacity to digest organic material from vegetal origin, which is supported by their higher digestive enzyme capacities, in particular in $\alpha$-amylase activity, observed in males compared to females caught in Galicia (Rotllant et al. 2013). In our study, higher $\delta^{15} \mathrm{~N}$ values were observed in Atlantic populations than in Mediterranean ones, as previously reported for other species (e.g. Borrell et al. 2006, Gómez-Díaz and González-Solís 2007, Giménez et al. 2013).

The results reported here are useful for product traceability. In the Spanish market, during the whole year, but particularly during the spider crab closed season (May to November approximately, annual variations depending on total fishing quotas), the fisheries market is supplied by $M$. brachydactyla specimens caught in Ireland, France, the United Kingdom and/or Morocco (Mercasa 2007), although crabs from Galicia fetch higher prices. In this study, stable isotope signatures for commercial Maja species allow their geographical origin of capture to be identified. Thus, this methodology could be used for fisheries management to identify the origin of the product, prevent fraud and guarantee its traceability along the commercial chain.

\section{ACKNOWLEDGEMENTS}

Financial support was provided by the Ministry of Science and Research to GG (post-doctoral fellowship; INIA). Bench fees were provided by JACUMAR (REPES project) to GR.

\section{REFERENCES}

Abelló P. 1989. Feeding habits of Macropipus tuberculatus (Brachyura, Portunidae) off the Catalan coast (NW Mediterranean). Misc. Zool. 13: 45-50.

Abelló P., Cartes J. 1987. Observaciones sobre la alimentación de Liocarcinus depurator (L.) (Brachyura: Portunidae) en el Mar Catalán. Invest. Pesq. 51(Supl. 1): 413-419.

Abelló P., Guerao G., Salmerón F., et al. 2014. Maja brachydactyla (Brachyura: Majidae) in the western Mediterranean. Mar. Biodivers. Rec. 7: 1-5. http://dx.doi.org/10.1017/S1755267214000827

Bennett D.B., Brown C.G. 1983. Crab (Cancer pagurus) migrations in the English Channel. J. Mar. Biol. Assoc. U.K. 63: 371-398. http://dx.doi.org/10.1017/S0025315400070740

Bernárdez C., Freire J., González-Gurriarán E. 2000. Feeding of the spider crab Maja squinado in rocky subtidal areas of the Ría de Arousa (north-west Spain). J. Mar. Biol. Assoc. U.K. 80: 95-102. http://dx.doi.org/10.1017/S0025315499001605

Bligh E.G., Dyer W.J. 1959. A rapid method of total lipid extraction and purification. Can. J, Biochem. Phys. 37: 911-917.

Bodin N., Le Loc'h F., Hily C., et al. 2007. Variability of stable isotope signatures $\left(\delta^{13} \mathrm{C}\right.$ and $\left.\delta^{15} \mathrm{~N}\right)$ in two spider crab populations (Maja brachydactyla) in Western Europe. J. Exp. Mar. Biol. Ecol. 343: 149-157. http://dx.doi.org/10.1016/j.jembe.2006.09.024

Borrell A., Aguilar A., Tornero V., et al. 2006. Organochlorine compounds and stable isotopes indicate bottlenose dolphin subpopulation structure around the Iberian Peninsula. Environ. Int. 32: 516-523. http://dx.doi.org/10.1016/j.envint.2005.12.001 
Bosc E., Bricaud A., Antoine D. 2004. Seasonal and interannual variability in algal biomass and primary production in the Mediterranean Sea, as derived from 4 years of SeaWiFS observations. Global Biogeochemical Cycles 18: GB1005. http://dx.doi.org/10.1029/2003GB002034

Bunn S.E., Loneragan N.R., Kempster M.A. 1995. Effects of acid washing on stable isotope ratios of $\mathrm{C}$ and $\mathrm{N}$ in penaeid shrimp and seagrass: implications for food-web studies using multiple stable isotopes. Limnol. Oceanogr. 40: 622-625. http://dx.doi.org/10.4319/1o.1995.40.3.0622

Cardona L., Revelles M., Sales M., et al. 2007. Meadows of the seagrass Posidonia oceanica are a significant source of organic matter for adjoining ecosystems. Mar. Ecol. Prog. Ser. 335: $123-131$. http://dx.doi.org/10.3354/meps335123

Cherel Y., Hobson K.A. 2005. Stable isotopes, beaks, and predators: a new tool to study the trophic ecology of cephalopods, including giant and colossal squids. Proc. R. Soc. B 272: 1601-1607. http://dx.doi.org/10.1098/rspb.2005.3115

Choy C. 1986. Natural diet and feeding habits of the crabs Liocarcinus puber and L. holsatus (Decapoda, Brachyura, Portunidae). Mar. Ecol. Prog. Ser. 31: 87-99. http://dx.doi.org/10.3354/meps031087

Corgos A., Sampedro M.P., González-Gurriarán E., et al. 2007. Growth at moult, intermoult period and moulting seasonality of the spider crab Maja brachydactyla: combining information from mark-recapture and experimental studies. J. Crust. Biol. 27: 255-262. http://dx.doi.org/10.1651/C-2626.1

De Kergariou G. 1971. L'araignée de mer, Maia squinado L., sur le littoral de Bretagne. Science et Pêche, Bulletin d'Institute des Pêches maritimes 205: 11-19.

De Kergariou G. 1974. Régime alimentaire de Maja squinado. International Council for the Exploration of the Sea 1974/K, 36, 6 pp.

De Kergariou G. 1984. L'araignée de mer, H. Biologie et exploitation. La Pêche maritime 1279: 575-583.

Drago M., Cardona L., Crespo E.A., et al. 2009. Ontogenic dietary changes in South American sea lions. J. Zool. 279: 251-261. http://dx.doi.org/10.1111/j.1469-7998.2009.00613.x

Eder E., Ceballos A., Martins S., et al. 2012. Foraging dichotomy in loggerhead sea turtles Caretta caretta off northwestern Africa. Mar. Ecol. Prog. Ser. 470: 113-122. http://dx.doi.org/10.3354/meps10018

Fahy E., Carroll J. 2009. Vulnerability of male spider crab Maja brachydactyla (Brachyura: Majidae) to a pot fishery in southwest Ireland. J. Mar. Biol. Assoc. U.K. 89: 1353-1366. http://dx.doi.org/10.1017/S0025315409000083

Freire J., Bernárdez C., Corgos A., et al. 2002. Management strategies for sustainable invertebrate fisheries in coastal ecosystems of Galicia (NW Spain). Aquat. Ecol. 36: 41-50. http://dx.doi.org/10.1023/A:1013350723445

Freire J., Carabel S., Verísimo P., et al. 2009. Patterns of juvenile habitat use by the spider crab Maja brachydactyla as revealed by stable isotope analyses. Sci. Mar. 73: 39-49. http://dx.doi.org/10.3989/scimar.2009.73n1039

Giménez J., Gómez-Campos E., Borrell A., et al. 2013. Isotopic evidence of limited exchange between Mediterranean and eastern North Atlantic fin whales. Rapid Commun. Mass Spectrom. 27: 1801-1806. http://dx.doi.org/10.1002/rcm.6633

Gómez-Díaz E., González-Solís J. 2007. Geographic assignment of sea birds to their origin: combining morphologic, genetics, and biochemical analyses. Ecol. Appl. 17: 1484-1498. http://dx.doi.org/10.1890/06-1232.1

González-Gurriarán E., Freire J. 1994. Movement patterns and habitat utilization in the spider crab Maja squinado (Herbst) (Decapoda, Majidae) measured by ultrasonic telemetry. J. Exp. Mar. Biol. Ecol. 184: 269-291. http://dx.doi.org/10.1016/0022-0981(94)90009-4

González-Gurriarán E., Freire J., Parapar J., et al. 1995. Growth at moult and moulting seasonality of the spider crab, Maja squinado (Herbst) (Decapoda: Majidae) in experimental conditions: implications for juvenile life history. J. Exp. Mar. Biol. Ecol. 189: 183-203.

http://dx.doi.org/10.1016/0022-0981(95)00023-K

González-Gurriarán E., Freire J., Bernárdez C. 2002. Migratory patterns of female spider crabs Maja squinado detected using electronic tags and telemetry. J. Crust. Biol. 22: 91-97. http://dx.doi.org/10.1651/0278-0372(2002)022[0091:MPOFS $\mathrm{C}] 2.0 . \mathrm{CO} ; 2$
Graham B.S., Koch P.L., Newsome S.D., et al. 2010. Using isoscapes to trace the movements and foraging behavior of top predators in oceanic ecosystems. In: West J.B., Bowen G.J., Dawson T.E., et al. (eds), Isoscapes: Understanding Movement, Pattern and Process on Earth Through Isotope Mapping. Springer, New York, pp. 299-318. http://dx.doi.org/10.1007/978-90-481-3354-3_14

Guerao G., Rotllant G. 2010. Development and growth of the early juveniles of the spider crab Maja squinado (Brachyura: Majoidea) in an individual culture system. Aquaculture 307: 105-110. http://dx.doi.org/10.1016/j.aquaculture.2010.06.006

Guerao G., Andree K.B., Froglia C., et al. 2011. Identification of european species of Maja (Decapoda, Brachyura, Majidae): RFLP analyses of COI mtDNA and morphological considerations. Sci. Mar. 75: 129-134. http://dx.doi.org/10.3989/scimar.2011.75n1129

Hines A.H., Lipcius R.N., Haddon A.M. 1987. Population dynamics and habitat partitioning by size, sex, and molt stage of blue crabs Callinectes sapidus in a subestuary of central Chesapeake Bay. Mar. Ecol. Prog. Ser. 36: 55-64. http://dx.doi.org/10.3354/meps036055

Hines A.H., Wolcott T.G., González-Gurriarán E., et al. 1995. Movement Patterns and Migrations in Crabs: Telemetry of Juvenile and Adult Behaviour in Callinectes sapidus and Maja squinado. J. Mar. Biol. Assoc. U.K. 75: 27-42. http://dx.doi.org/10.1017/S0025315400015174

Hirons A., Schell D.M., St Aubin D.J. 2001. Growth rates of vibrissae of harbor seals (Phoca vitulina) and Steller sea lions (Eumetopias jubatus). Can. J. Zool. 79: 1053-1061. http://dx.doi.org/10.1139/z01-055

Hobson K.A. 1999. Tracing origins and migration of wildlife using stable isotopes: a review. Oecologia 120: 314-326. http://dx.doi.org/10.1007/s004420050865

Hobson K.A., Wassena L.I., Taylo O.R. 1999. Stable isotopes ( $\delta$ D and $\delta^{13} \mathrm{C}$ ) are geographic indicators of natal origins of monarch butterflies in eastern North America. Oecologia 120: 397-404. http://dx.doi.org/10.1007/s004420050872

Jackson A.L., Parnell A.C., Inger R., et al. 2011. Comparing isotopic niche widths among and within communities: SIBER - Stable Isotope Bayesian Ellipses in R. J. Anim. Ecol. 80: 595-602. http://dx.doi.org/10.1111/j.1365-2656.2011.01806.x

Koch P.L. 2008. Isotopic Study of the Biology of Modern and Fossil Vertebrates. In: Michener, R., Lajtha, K. (eds) Stable Isotopes in Ecology and Environmental Science, Oxford, Blackwell Publishing Ltd, pp. 99-154.

Layman C.A., Arrington D.A., Montanä C.G., et al. 2007. Can stable isotope ratios provide for community-wide measures of trophic structure? Ecology 88: 42-48. http://dx.doi.org/10.1890/0012-9658(2007)88[42:CSIRPF] 2.0.CO;2

Longhurst A. 1998. Ecological geography of the sea. Academic Press.

Martín P., Maynou F., Stelzenmüller V., et al. 2012. A small-scale fishery near a rocky littoral marine reserve in the northwestern Mediterranean (Medes Islands) after two decades of fishing prohibition. Sci. Mar. 76: 607-618. http://dx.doi.org/10.3989/scimar.03471.07F

Martínez del Río C., Wolf N., Carleton S.A., et al. 2009. Isotopic ecology ten years after a call for more laboratory experiments. Biol. Res. 84: 91-111. http://dx.doi.org/10.1111/j.1469-185X.2008.00064.x

Mercasa 2007. El centollo. Distribución y Consumo 93: 86-89.

Neumann V. 1996. Comparative investigations on the systematics and taxonomy of European Maja species (Decapoda, Brachyura, Majidae). Crustaceana 69: 821-852. http://dx.doi.org/10.1163/156854096X00222

Neumann V. 1998. A review of the Maja squinado (Crustacea: Decapoda: Brachyura) species-complex with a key to the eastern Atlantic and Mediterranean species of the genus. J. Nat. Hist. 32: $1667-1684$. http://dx.doi.org/10.1080/00222939800771191

Ng P.K.L., Guinot D., Davie P.J.F. 2008. Systema Brachyurorum: Part I. An annotated checklist of extant Brachyuran crabs of the world. Raffles Bull. Zool. 17 (Suppl.): 1-286.

Pantoja S., Repeta D.J., Sachs J.P., et al. 2002. Stable isotope constraints on the nitrogen cycle of the Mediterranean Sea water column. Deep-Sea Res. I 49: 1609-1621. http://dx.doi.org/10.1016/S0967-0637(02)00066-3

Parnell A.C, Inger R., Bearhop S., et al. 2010. Source Partitioning 
Using Stable Isotopes: Coping with Too Much Variation. PLoS One 5: e9672.

http://dx.doi.org/10.1371/journal.pone.0009672

Pinela A.M., Borrell A., Cardona L., et al. 2010. Stable isotope analysis reveals habitat partitioning among marine mammals off the NW African coast and unique trophic niches for two globally threatened species. Mar. Ecol. Prog. Ser. 416: 295-306. http://dx.doi.org/10.3354/meps08790

Pons Muñoz J.M. 1994. Menorca y su pesca. Arial.

Post D.M. 2002. Using stable isotopes to estimate trophic position: models, methods, and assumption. Ecology 83: 703-718. http://dx.doi.org/10.1890/0012-9658(2002)083[0703:USITET] 2.0.CO;2

R Core Team. 2013. R: A language and environment for statistical computing. R Foundation for Statistical Computing. Vienna, Austria. URL: http://www.R-project.org

Rodhouse D.M. 1984. Experimental fishing for the spider crab, Maia squinado: sea and laboratory trials. J. Mar. Biol. Assoc. U.K. 64: 251-259. http://dx.doi.org/10.1017/S0025315400029969

Rotllant G., Roque A., Solé M., et al. 2013. Assessment of the effects of confinement in the spider crab Maja brachydactyla Blass, 1922 broodstock. Aqua. Res. 44: 412-426. http://dx.doi.org/10.1111/j.1365-2109.2011.03046.x

Sampedro M.P., González-Gurriarán E., Freire J., et al. 1999. Morphometry and sexual maturity in the spider crab Maja squinado (Decapoda, Majidae) in Galicia, Spain. J. Crust. Biol. 19: 578-592. http://dx.doi.org/10.2307/1549263

Somes C.J., Schmittner A., Galbraith E.D., et al. 2010. Simulating the global distribution of nitrogen isotopes in the ocean. Global Biogeochem. Cy. 24, GB4019. http://dx.doi.org/10.1029/2009GB003767

Sotelo G., Morán P., Posada D. 2008. Genetic identification of the northeastern Atlantic spiny spider crab as Maja brachydactyla Balss, 1922. J. Crust. Biol. Biology 28: 76-81. http://dx.doi.org/10.1651/07-2875R.1

Sotelo G., Morán P., Posada D. 2009. Molecular phylogeny and biogeographic history of the European Maja spider crabs (Decapoda, Majidae). Mol. Phylogenet. Evol. 53: 314-319. http://dx.doi.org/10.1016/j.ympev.2009.05.009

Spivak E., Anger K., Luppi T., et al. 1994. Distribution and habitat preferences of two grapsid crab species in Mar Chiquita Lagoon (Province of Buenos Aires, Argentina). Helgolaender Meeresun. 48: 59-78. http://dx.doi.org/10.1007/BF02366202

Števčić Z. 1967. Le complexe de la nourriture de l'araignée de mer Maja squinado. Helgolander Wiss. Meer. 15: 630-636. http://dx.doi.org/10.1007/BF01618656

Števčić Z. 1973. Les migrations de l'Araignée de mer. Rapport Commission International pour l'Exploration Scientifique de la Mediterranée 21: 597-598.

UNEP 1996. Acta final de la reunión de plenipotenciarios sobre los anexos del protocolo referente a las zonas especialmente protegidas y la diversidad biológica en el Mediterráneo. UNEP(OCA)/MED IG 10/4, 2 diciembre 1996.

Vernet G., Charmantier-Daures M. 1994. Mue, Autotomie et régénèration. In: Masson (ed) Traité de Zoologie. Anatomie, Systématique, Biologie. Tome VII, Fascicule I: Crustacés. Morphologie, Physiologie, Reproduction, Systématique. Paris, France: pp. 107-155.

Yokoyama H., Tamaki A., Harada K., et al. 2005. Variability of diet-tissue isotopic fractionation in estuarine macrobenthos. Mar. Ecol. Pro. Ser. 296: 115-128. http://dx.doi.org/10.3354/meps296115

Zariquiey-Álvarez R. 1968. Crustáceos Decápodos Ibéricos. Invest. Pesq. 32: 1-510. 